Jpn. J. Pharm. Health Care Sci.

ノ - ト 35(8) 585-591 (2009)

\title{
がん化学療法におけるレジメン別疑義照会の検討
}

近藤多実子*，神杉香代子，青山 剛，角田 尚，庄司大悟，

陳 紫玉, 式部さあ里, 川上和宜, 濱 敏弘

財団法人癌研究会有明病院薬剂部

\section{Analysis of Inquiries Concerning Cancer Chemotherapy for Individual Regimens}

Tamiko Kondo*, Kayoko Kamisugi, Takeshi Aoyama, Takashi Tsunoda, Daigo Shouji, Shigyoku Chin, Sari Shikibu, Kazuyoshi Kawakami and Toshihiro Hama

Department of Pharmacy, Japanese Foundation

for Cancer Research Cancer Institute Hospital

$\left[\begin{array}{l}\text { Received January 9, } 2009 \\ \text { A ccepted June 1, } 2009\end{array}\right]$

At the time of introduction of the electronic medical records system, we introduced additional systems such as those for chemotherapy regimen registration and prescription inspection in order to carry out cancer chemotherapy treatments safely.

Later, on conducting an investigation of 139,615 prescriptions for injectable agents from September 2006 to A ugust 2007, we found that our systems had reduced the numbers of inquiries such as those concerning omissions and overdosage. There were 407 inquiries concerning the 16,287 anticancer agent prescriptions among them and they uncovered prescribing errors such as selection of wrong regimens and making mistakes in cycle counts, that could have led to medical malpractice. We also found that inquiry rates were higher for breast cancer and colorectal cancer regimens.

Our findings indicated that mechanical prescription checking systems alone are not sufficient for ensuring safe treatment with anticancer agents and therefore the checking of prescriptions by pharmacists is considered to be very important.

Key words — anticancer agent, cancer chemotherapy, prescription checking, regimen, pharmacist, inquiries

\section{緒言}

1980 年代のプラチナ系抗がん薬の登場，1990年代の タキサン系抗がん薬の登場, 光して 2000 年代になって からの分子標的治療薬の登場で, がん化学療法による治 療成績が著しく向上し, 患者の生存率やQOL の向上を もたらしている．しかし一方で, 抗がん薬治療は重篤な 血液毒性, 消化器症状, アレルギーなどが高頻度で発生 する.また，分子標的治療薬においては, 従来の抗がん 薬とは異なる重篤な副作用が発現している．抗がん薬の 選択，投与量，投与間隔を誤ると，重大な事故につなが

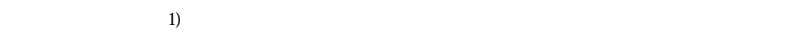
正使用と安全管理の両面から積極的にシステム構築に関 与することが求められている21.

癌研究会有明病院(以下, 当院と略す)では, 2005 年 4 月より電子カルテシステムを導入し，抗がん薬注射剤の
オーダーは, 個別に薬剂を選択するのではなく，がん種 と登録されたがん化学療法レジメン(以下，レジメンと 略す)を選択する方式を採用している．レジメンを選択 すると, 支持療法薬を含む一連の薬剤が展開されるとと もに，休薬完了日まで他のレジメンを選択できなくして いる.当院では，これをパスレジメンと称している．こ のシステムの導入により，正確かつ効率的に処方できる ようになった . 手書き処方せんの場合に起こっていた用 法の記載忘れや, 薬阂の規格に関する疑義照会はほぼ根 絶することができた . また ，処方鑑査システムの導入に よって，過量投与や重複投与についてもある程度チェッ クできるようになった ${ }^{3)}$.しかし , 上記システム導入後 も依然として抗がん薬注射処方に関して，疑義照会が行 われている

がん化学療法における疑義照会についてはこれまでに 医療経済学的検討 ${ }^{4.5}$ や，無菌調製担当薬斉師と病棟担当 薬斉師による疑義照会内容の比較分析 ${ }^{\circledR}$ などが報告され 
ている．しかしながら，がん化学療法をレジメン別とい う観点から疑義照会を検討した報告はこれまでにない． 弚こでわれわれは, 電子カルテシステム導入後もなお 発生するがん化学療法に関する疑義照会について，炎の 内容を8項目に分類し, 調査, 比較を行った .

さらに，疑義照会方法の検討も行った . 通常，レジメ ンに基づく処方鑑査を行い，疑義照会を行う場合，鑑査 をした薬斉師が電話連絡にて問い合わせを行ってきた . 今回の調査結果から, 疑義照会の件数が多かった消化器 科と乳腺科については, 鑑査を行った薬剂師は病棟と外 来治療センター(ATC : A mbulatory Therapy Center)に常 駐している薬剂師へ照会内容を伝え, 病棟常駐薬斉師か ら光の場にいる医師へ直接疑義照会を行うことにした。 产の後の疑義照会件数の変化についても評価を行った .

\section{対象および方法}

\section{1. 調査期間と方法}

2006 年 9 月から 2007 年 8 月までの 1 年間の疑義照会 内容をレジメン別に集計した .

また, 病棟常駐薬剂師が直接疑義照会を行うこととし た後の，2008年 2 月から 2008 年 4 月までの 3 力月間の 疑義照会内容をレジメン別に集計し比較した。

\section{2. 疑義照会内容の分類}

パスレジメンに登録されている，プレメディケーショ ン , ポストメディケーションなどの支持療法薬や，ハイ ドレーションなどの輸液に関する疑義照会も抗がん薬に かかわる疑義照会として集計した .

疑義照会の内容は(1)コース数のカウント間違い，(2)投 与量 , (3)プレメディケーション・ポストメディケーショ ン，(4)休薬期間，(5)レジメン選択，(6)重複処方，(7)規定 コース数の超過, および8)钅の他の8項目に分類した .

医師が実際の実施コース数とは違うコース数で処方し た場合を「(1)コース数のカウント間違い」, 総コース数 や，総投与量に上限がある薬剂(リツキシマブ注や，ド キソルビシン注 , ブレオマイシン注など)を含むレジメ ンに規定されているコース数を超えての処方を，「(7) コース数の超過」として集計した．

\section{3. 疑義照会方法}

通常は，処方鑑査を行った薬斉師から，医師へ直接電 話にて問い合わせを行っている .

疑義照会方法の検討後, 消化器科と乳腺科への問い合 わせは, 処方鑑査を行った薬斉師から病棟やATCに常 駐している薬剂師へ連絡し, 病棟薬剂師が医師に直接 会って疑義照会を行った。

\section{結 果}

1. 2006 年 9 月から 2007 年 8 月 1)処方せん枚数と疑義照会件数

対象期間内の全注射処方せん枚数は 139,615枚であ り，弚のうち抗がん薬注射処方せんは 16,287 枚(11.6\%) であった .この期間の疑義照会件数は 715 件であり，抗 がん薬注射に関する疑義照会は 407 件(56.9\%)を占めた。 2)レジメン別の処方件数と疑義照会率

2006 年 9 月から 2007 年 8 月までのレジメン別処方件 数と疑義照会率を図 1 に示す. 主なレジメンはWPAC 療法 3,381 件, HER 療法 3,200 件, FOLFOX 4 療法 2,470 件であった . 処方件数に対する疑義照会率をみると，上 位 3レジメンは，GEP 療法(6.5\%)，G-sy 療法(5.4\%)， FOLFOX 4療法(3.9\%)であった .

3)抗がん薬注射処方における疑義照会

抗がん薬注射処方の疑義照会 407 件の内容を図 2 に示 す. 最も多いのは, コース数のカウント間違いであり， 287 件(71\%)を占め, 次いで投与量 59 件(15\%)であり， プレメディケーション・ポストメディケーション 21 件 (5\%)を加えた上位 3つで全体の 91\% を占めた . そのほ かに休薬期間，レジメン選択，重複処方，規定コース数 の超過などに関する照会があった．事例ついては表 1 に 示す.

4)コース数のカウント間違いにおける疑義照会

コース数のカウント間違い 287 件をレジメン別に図 3 に示す.FOLFOX 4 療法 81 件(28\%), WPAC療法 31 件 (11\%)，G-sy 療法 34件(8\%)，FOLFIRI 療法 23件(8\%), HER 療法 22 件(8\%)であつた .

5)GEP 療法, G-Sy 療法, FOLFOX 4 療法における疑 義照会

疑義照会率が高い上位 3レジメンを図 4 に示す．

GEP 療法では処方件数 124 件のうち，疑義照会は 8 件(6.5\%)であり，光の内容はコース数のカウント間違い 7 件 , 投与量 1 件であった .

G-sy 療法では処方件数 702 件のうち，疑義照会は 38 件(5.4\%)であり，光の内容はコース数のカウント間違い 34 件(89\%)，投与量 2件(5\%)，休薬期間 1件(3\%)，重 複処方 1件(3\%)であった .

FOLFOX 4 療法では処方件数 2,470 件のうち，疑義照 会は 97 件(3.9\%)であり，光の内容はコース数のカウン 卜間違い 81 件 $(84 \%)$ ，投与量 13件(13\%)であった．光 のほかはプレメディケーション・ポストメディケーショ ン，休薬期間，レジメン選択に関する疑義照会があつ た.

\section{6)WPAC 療法の疑義照会数の比較}

当院では, WPAC 療法は進行再発がんまたは, 術前術 後補助化学療法として用いられているWPAC 療法の疑 義照会について, 光れ光れの疑義照会件数の比較を行っ た . 2006 年 9 月から 2007 年 8 月の 1 年間の WPAC 療法 


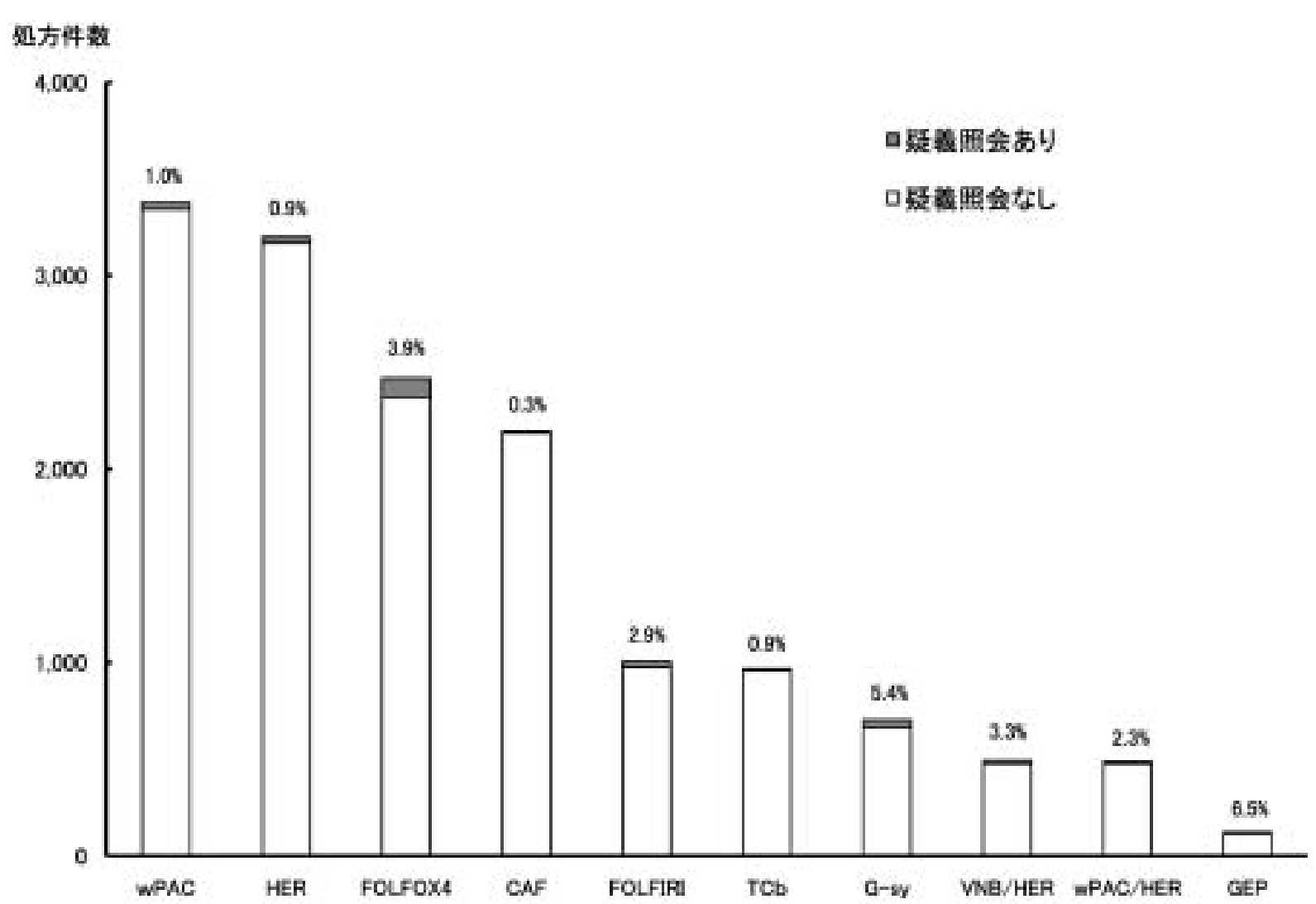

図 1.2006 年 9 月から 2007 年 8 月におけるレジメン別の処方件数と疑義照会率

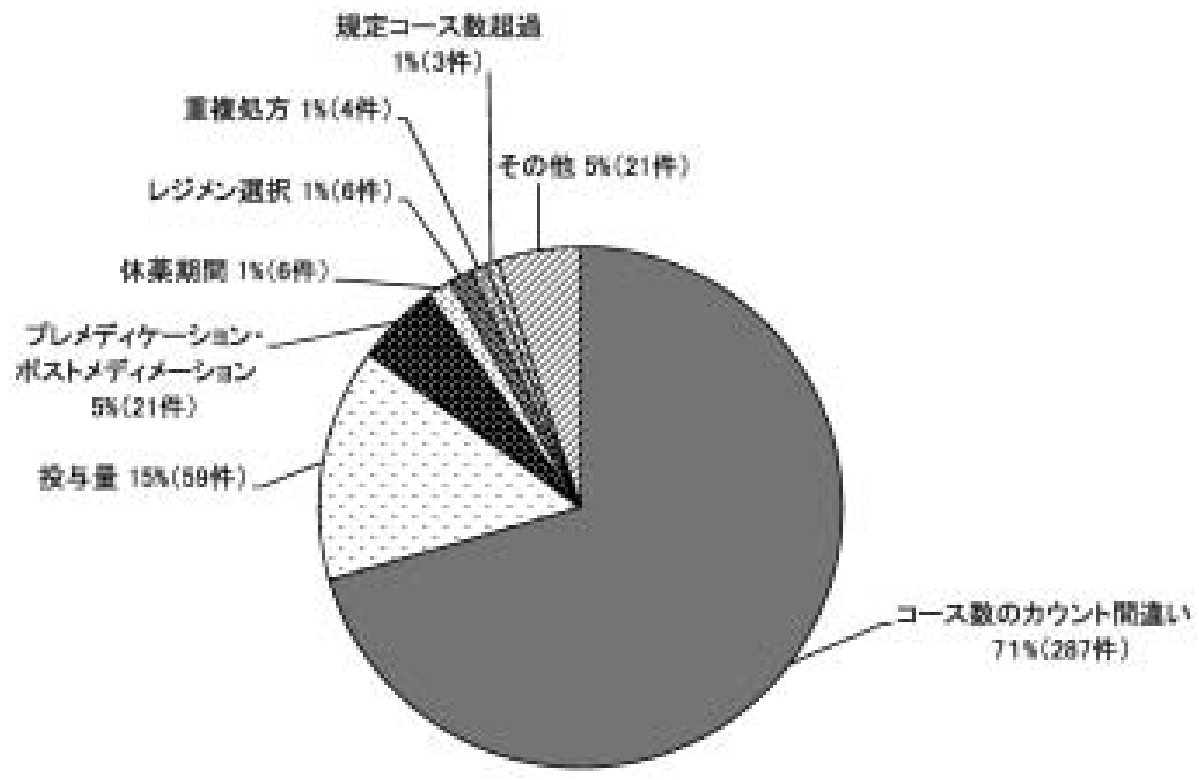

図 2 . 抗がん薬注射における疑義照会の内容 $(n=407$ 件 $)$

の疑義照会 35 件のうち，進行再発 25 件(71\%)，術前術 後補助 10 件(29\%)であった .

2. 疑義照会件数の変化 消化器科と乳腺科に常駐する薬斉師から医師へ直接の
疑義照会を実施した前後での件数の変化を図 5 に示す． 2006 年 9 月から 2007 年 8 月の 12 力月間に消化器科で は, 平均で 12.8 件/月の疑義照会を行っていたが， 2008 年 2 月から 4 月の 3 力月間では 6.7 件/月に減少した . また, 乳腺科でも 8.8 件/月から 3.5 件/月に減少した。 
表 1 . ファーマシューティカルケア事例

\begin{tabular}{|c|c|c|c|c|c|}
\hline 疑義照会分類 & がん種 & レジメン名 & 疑義照会前 & 疑義照会内容 & 疑義照会後 \\
\hline \multirow{2}{*}{ 投与量 } & |悪性リンパ腫 & DHAP & $\begin{array}{l}\text { シタラビン注 } 2 \mathrm{~g} / \mathrm{m}^{2} を \\
80 \% \text { \%量で1日2回の処方 } \\
\text { であった。 }\end{array}$ & 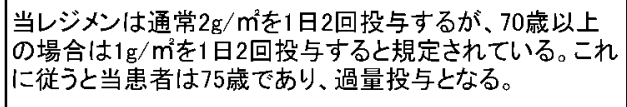 & $\begin{array}{l}\text { シタラビン注 } 1 \mathrm{~g} / \mathrm{m}^{2} を 1 \\
\text { 日2回に変更となった。 }\end{array}$ \\
\hline & |悪性リンパ腫 & hyper CVAD & $\begin{array}{l}\text { 前コ一スと抗がん薬の } \\
\text { 投与量が同じであっ } \\
\text { た。。 }\end{array}$ & $\begin{array}{l}\text { 当院では10\%以上の体重変動がある場合、最新の体重 } \\
\text { を用いた体表面積で投与量を再計算すると㚘定がある。 }\end{array}$ & \begin{tabular}{|l|} 
最新の体表面積で再 \\
計算された投量に変 \\
更となった。
\end{tabular} \\
\hline \multirow{2}{*}{$\begin{array}{l}\text { プレメディケー } \\
\text { ショシ・ポストメ } \\
\text { ディケーション }\end{array}$} & 乳がん & CAF & $\begin{array}{l}\text { デキサメタゾン注 } 20 \mathrm{mg} \\
\text { の処方であった。 }\end{array}$ & 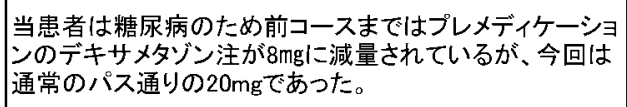 & $\begin{array}{l}\text { デキサメタゾン注 } 8 \mathrm{mg} \\
\text { 減量となった。 }\end{array}$ \\
\hline & |悪性リンパ腫 & $\mathrm{R}-\mathrm{CHO}$ & $\begin{array}{l}\text { 制吐剤なしの処方で } \\
\text { あった。 }\end{array}$ & $\begin{array}{l}\text { 当患者は胃潰瘍のため、プレドニン゙ロン注の処方が削除 } \\
\text { となっている緒に処方されている制吐绪も削除 } \\
\text { されていた。 }\end{array}$ & $\begin{array}{l}\text { 追加で制吐剂グラニセ } \\
\text { トロン注が処方となっ } \\
\text { た。 }\end{array}$ \\
\hline 休薬期間 & 直腸がん & FOLFOX4 & $\begin{array}{l}\text { FOLFOX4療法からの } \\
\text { レジメン変更で、12日 } \\
\text { 間の休楽後にLow } \\
\text { dose FP療法開始の処 } \\
\text { 方であった。 }\end{array}$ & $\begin{array}{l}\text { ᄀルオロウラシル注が重複するので14日以上の休薬が必 } \\
\text { 要である。 }\end{array}$ & $\mid \begin{array}{l}\text { Low dose FP療法は投 } \\
\text { 与延期となった。 }\end{array}$ \\
\hline \multirow{5}{*}{ レジメン選択 } & 乳がん & $3 w D O C$ & $\begin{array}{l}\text { EtOH溶解の3wDOC療 } \\
\text { 法のレジメンが選択さ } \\
\text { れていた。。 }\end{array}$ & 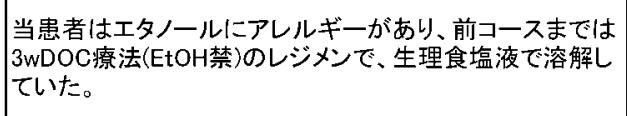 & \begin{tabular}{|}
$\mid$ 前コース同様 $3 w D O C$ \\
療法(EtOH禁)へレジ \\
メン変更となった。
\end{tabular} \\
\hline & 胃がん & $3 w D O C$ & $\begin{array}{l}\text { TS-1/DOC併用療法 } \\
\text { のレジメンが選択され } \\
\text { ていた。 }\end{array}$ & 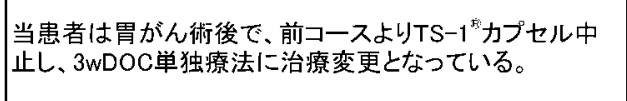 & $\begin{array}{l}\text { 前コ一ス同様 } 3 w D O C \\
\text { 単独療法へレジメン変 } \\
\text { 更となった。 }\end{array}$ \\
\hline & 胃がん & CPT-11/CDDP & $\begin{array}{l}\text { 食道がんのCPT- } \\
11 / \text { CDDP療法のレジメ } \\
\text { ンが選択されていた。 }\end{array}$ & $\begin{array}{l}\text { 当患者は食道がんでなく、男がんである。食道がん、胃 } \\
\text { がとも薬剂、投与量は同じであるが、休薬期間 } \\
\text { やコ一ス数の規定が異なる。 }\end{array}$ & \begin{tabular}{|l} 
胃がんのCPT- \\
11/CDDP療法へレジメ \\
シ変更となっ。
\end{tabular} \\
\hline & 大腸がん & FOLFOX4 & $\begin{array}{l}\text { FOLFOX66療法のレジメ } \\
\text { ンが選択されてた。 }\end{array}$ & 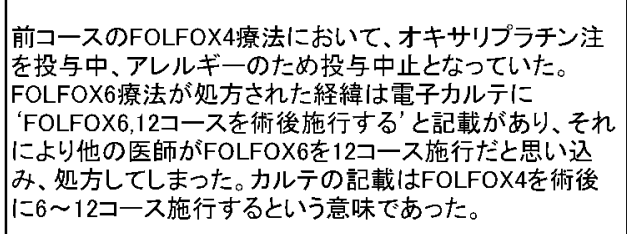 & $\begin{array}{l}\text { FOLFIRI療法へレジメ } \\
\text { ン変更となった。 }\end{array}$ \\
\hline & 原発不明がん & CPT-11/CDDP & $\begin{array}{l}\text { 非小細胞肺がんの } \\
\text { CPT-11/CDDP療法の } \\
\text { レジメンが選択されて } \\
\text { いた。 }\end{array}$ & 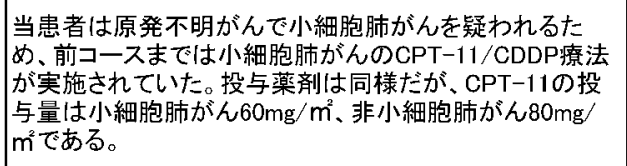 & $\begin{array}{l}\text { 前コースと同様の小細 } \\
\text { 胞肺がんのレジンへ } \\
\text { 変更となつた。 }\end{array}$ \\
\hline 規定コ一ス数 & |悪性リンパ腫 & |リツキサン & $\begin{array}{l}\text { リツキサンが9コース目 } \\
\text { の処方であった。 }\end{array}$ & リツキサンは8コ一スまでという総コ一ス数の規定がある。 & $\begin{array}{l}\text { 9コース目は中止となっ } \\
\text { た。 }\end{array}$ \\
\hline
\end{tabular}




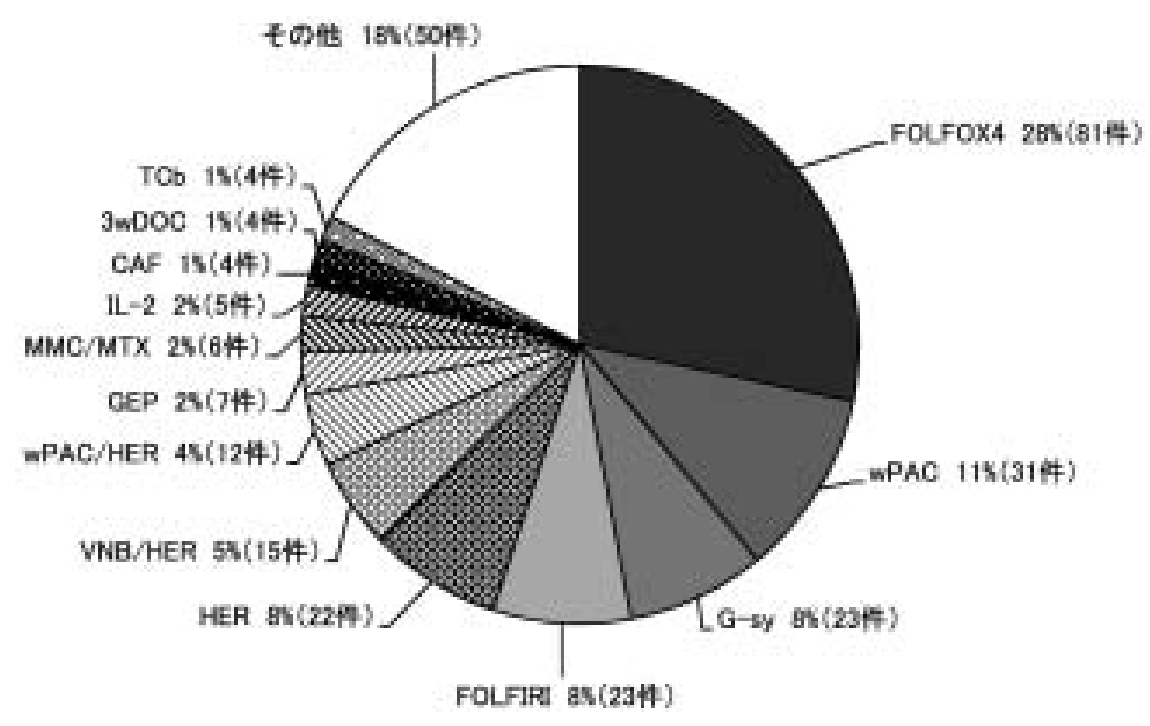

図 3 .コース数のカウント間違いにおける疑義照会 $(n=287)$ 〜レジメン別割合〜

考察

今回の調査により，抗がん薬注射処方に関してはレジ メンコース数のカウント間違いに関する疑義照会が最も 多かった . 図 2 に示すようにレジメン別にみると,FOLFOX 4 療法, G-sy 療法, FOLFIRI 療法, HER 療法など 進行再発がんでのみ用いられるレジメンが, 進行再発が んだけでなく術前術後補助化学療法でも用いられる WPAC 療法, CAF 療法, TCb 療法などのレジメンに比 較して, コース数のカウント間違いが多くみられた . 例 えば，処方件数が最も多いwPAC 療法の疑義照会は進 行再発がん $71 \%$, 術前術後補助補助化学療法 $29 \%$ の割 合であった . 進行再発がんに用いるレジメンでのコース 数に関する疑義照会が多いのは, 進行再発がんでの化学 療法は延命や患者のQOL 改善を目的としているため， 術前術後補助化学療法に比へ，患者の体調により投与量 が調節されることも多く，投与直前に投与延期となるこ とが多いためである.このため, コース数のカウントが 訂正されないと実施コース数と異なり，疑義照会の割合 が高くなったと考えられる．

コース数のカウント間違いが最も多かった FOLFOX 4 療法は, 処方件数も 2,470 件と多いうえ, 骨髄機能抑制 やオキサリプラチンの副作用である末梢神経障害やアレ ルギーといった理由から，投与延期となることが多いレ ジメンである．さらに，末梢神経障害やアレルギーは， コース数を重ねると起こりやすいことが報告されてい る゙.コース数を正確にカウントしていくことは, 副作 用が起こりやすい時期を把握することに役立ち, 患者に 副作用が起こりやすい時期を指導する際に有用である．

また , コース数のカウントは総コース数や, 総投与量 に上限規定がある薬剤が含まれるレジメンの管理にも有 効である .
当院薬斉部では，処方鑑査時，患者ごと作成している 薬歴ファイルのカレンダーにコース数を記載し, 確認を 行っている. 実際に実施されたコース数と異なるコース 数か拠方された場合, 医師へ疑義照会を行っている.

当院の電子カルテシステムでは,レジメンを選択する ことで抗がん薬だけでなく支持療法薬も含めて展開され るため，医師が手入力で薬剂を処方することはないが， コース数は例外であり, 自動的にカウントされずに実施 したコース数を医師が手入力しなくてはならない．投与 延期となって処方が肖除された場合，次回処方時にコー ス数は自動的に反映されない：このため，投与延期と なった場合に，コース数のカウント間違いが起きている と考えられる . 医師は電子カルテの使用方法の説明を十 分に受けている.しかし, 新人医師だけでなく, 経験豊 富な医師もミスを起こしていることから，今後，コース 数は実施確定または, 実施終了時の入カデータをもと に, 自動的にカウントされるようなシステムの改善か望 まれる。

過量投与に関する疑義照会では，体表面積から計算さ れる上限値を超えた投与量による照会はなかった．これ はシステム的に制御がかけられているためである . 当院 のシステムでは，患者の体表面積からレジメンで規制す る $100 \%$ 用量が自動計算される.弚のため，登録量の 100 \%を超える処方はできない仕樣となっている .このた め，上限值を超えた投与量による照会はなかった．しか し，前コースにおいて骨髄機能抑制などのため投与量を 80\% 量へ減量したにもかかわらず，今回のコースでは 再び減量前の投与量で処方された事例など薬歴チェック により，過量投与を未然に防いだケースがみられた .こ のような副作用や年齢規定による減量などのチェック は, 現在のシステムでは限界があり，薬歴による薬莿師 のチェックが必要である，乥こで薬斉部では, 毎回 , 投 


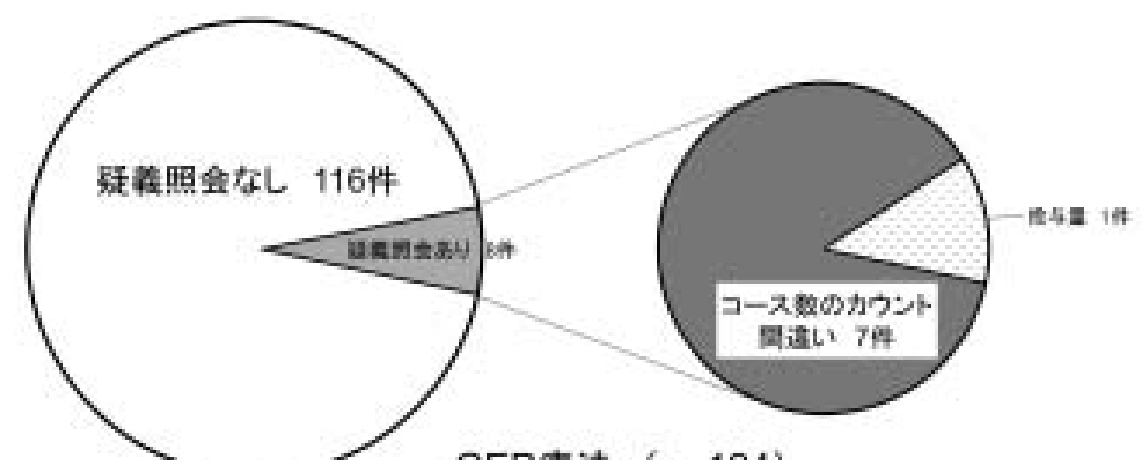

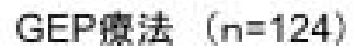
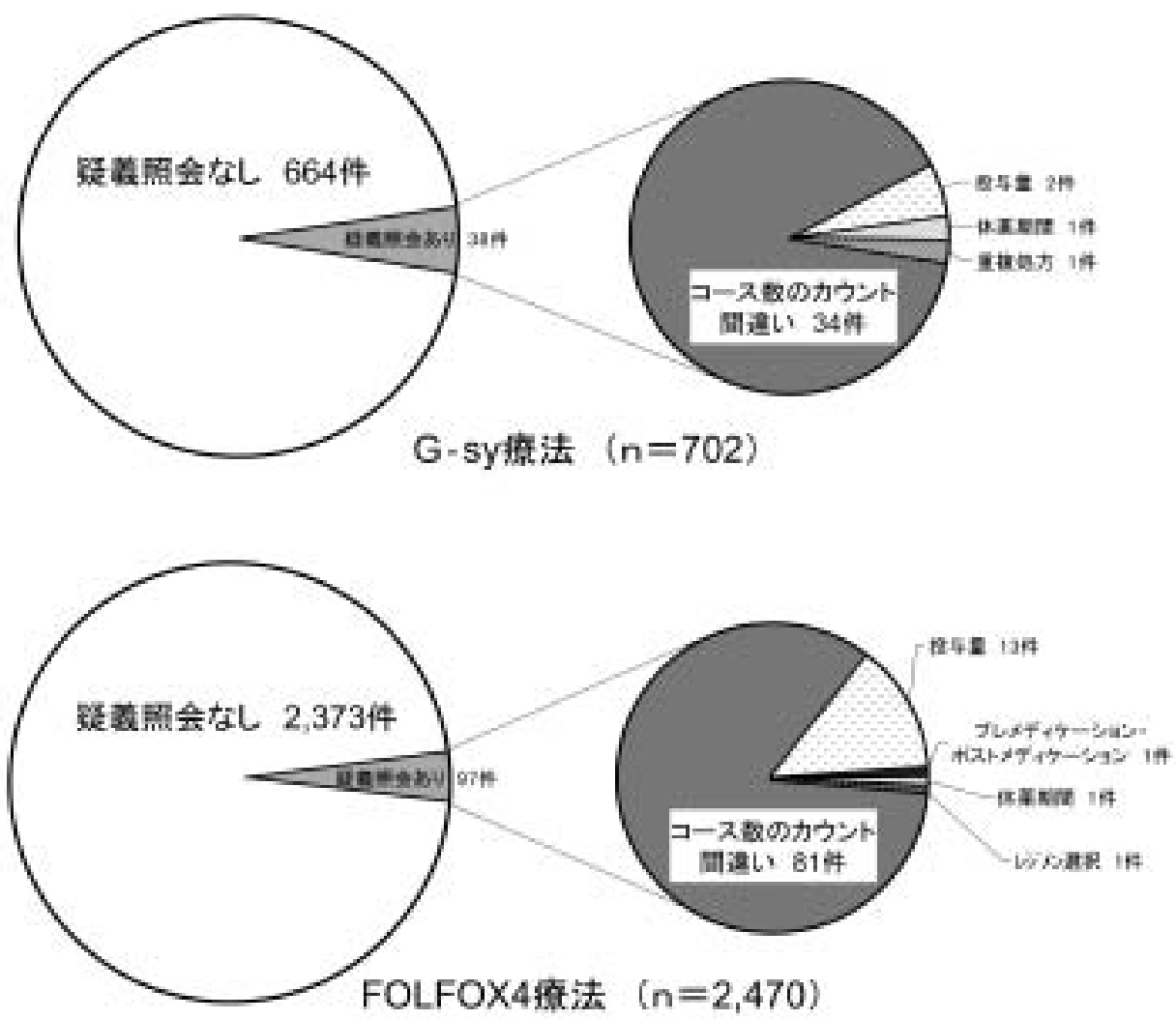

図 4 .レジメン別の疑義照会内容

与量を薬歴ファイルに記録を残し，薬歴管理を行ってい る. 前コースまでの投与量と照合し, 投与量か湾わった 場合，医師に処方量の確認を行い投与量の間違いによる 医療事故を未然に回避している。

さらに, 薬阂師によるチェックにより件数は少ない が, 表 1 に示すような適応レジメンの選択間違いを発見 できた、電子カルテシステム導入前にはなかったミスで ある、レジメン選択間違いは重大な医療事故につながり かねない．このため, 当院の薬㓢部では, 初回レジメン か拠方されたとき, 薬歴ファイルへ患者のがん種とレジ メン名を記載している.1コース目では小細胞肺がんの CPT-11/CDDP 療法を行っていた患者に2コース目では 非小細胞肺がんのレジメンが選択されていたという事例 があった . 投与薬㓢は同じだが，イリノテカン注の投与 量は小細胞肺がん $60 \mathrm{mg} / \mathrm{m}^{2}$, 非小細胞肺がん $80 \mathrm{mg} / \mathrm{m}^{2}$
と異なっている . 医師へ疑義照会し, 前回同樣に小細胞 肺がんのレジメンへ変更となった .これは, 患者ごとに 薬歴管理 , レジメンの照合がなされなければ発見が困難 な事例である.この事例から，薬斉師が処方鑑査時に投 与量や，休薬期間，コース数などの確認だけでなく，が ん種も確認することが重要であると考えられる．今後， がん登録時のがん種を反映し，患者のがん種とは異なる レジメンが選択されたときにエラーが表示されるような システムの変更か望まれる .

また，疑義照会内容をレジメン別に分類すると，全疑 義照会の上位 5 レジメンが消化器科と乳腺科で用いられ ているレジメンであることがわかった .この結果から， まず初めに疑義照会件数の多かった消化器科と乳腺科の 医師へ疑義照会の方法を変更した，すなわち，注射室勤 務の薬剤師が電話による疑義照会をするのでなく, 病棟 


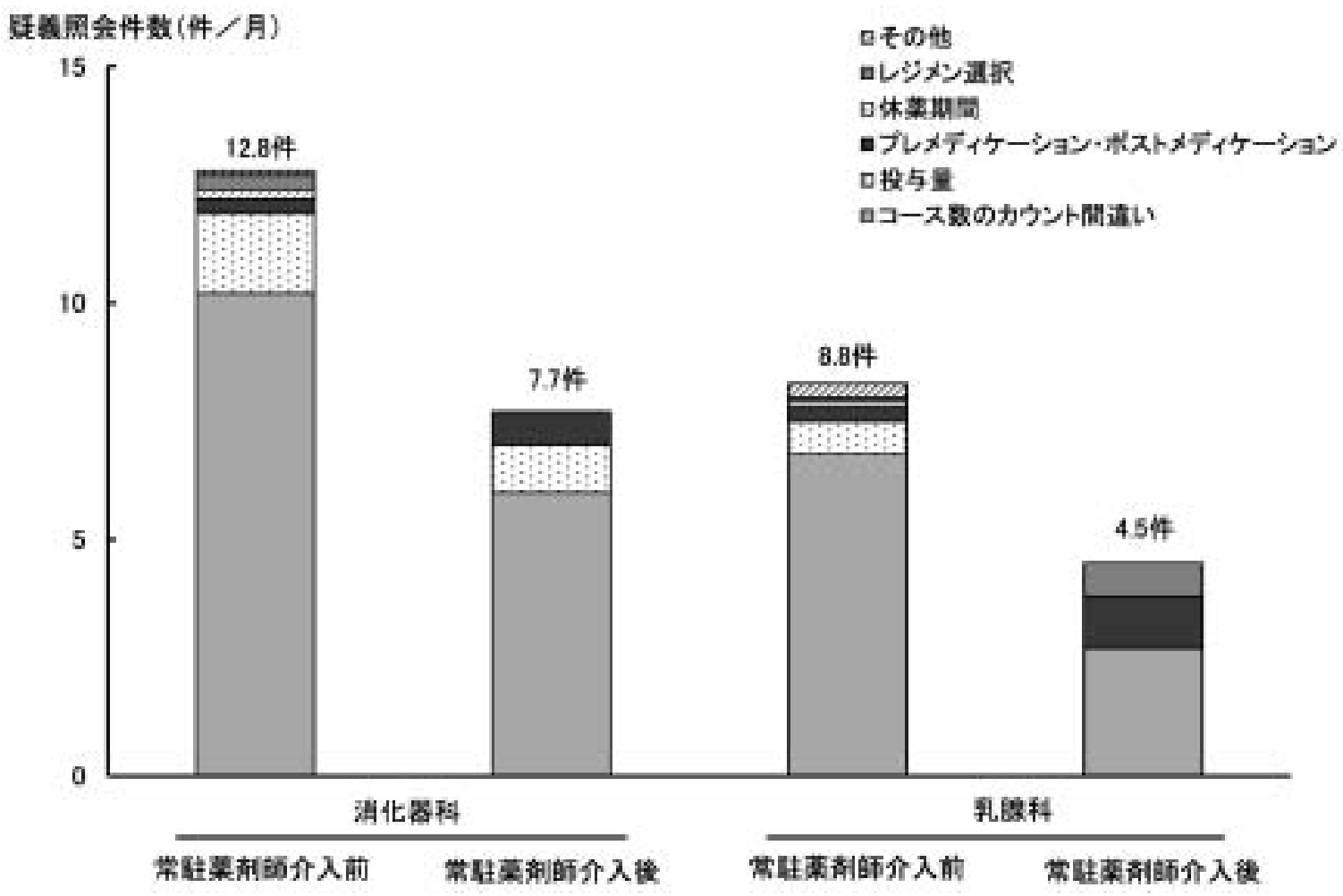

図 5. 常駐薬斉師介入前後での疑義照会件数の変化

と ATC に常駐する担当薬斉師が，直接医師に疑義照会 を行うこととした．抗がん薬の処方鑑査は，投与日の前 日までに実施するためこの方法が成立する．また，カン ファレンス等で薬斉師が疑義照会内容を報告し入力時の 注意喚起を行った .これにより，疑義照会の月平均件数 は消化器科が 12.8 件から 7.7 件, 乳腺科が 8.8 件から 4.5件へと光れ光れ約半数に減少した．この結果から， 医師に直接会って疑義照会を行う方法や，カンファレン スで注意喚起を行うことは有効であったといえる．電話 による疑義照会は，お互いの顔と关の場の状況が見えず 一方的になりがちであるが，病棟薬剂師が医師に直接問 い合わせることで, 疑義照会件数減少へつながったと考 えられる.今後は消化器科, 乳腺科だけでなくほかの診 療科でも行っていく予定である．また，院内の安全管理 委員会などで今回の疑義照会内容の検討結果を報告し， 注意喚起を行っていく予定である．

疑義照会件数は減少したが, ゼロにはならず, システ ムチェックだけでは対応できない処方ミスもあることか ら，患者ごとに紙べースの薬歴ファイルを用いて行う処 方鑑査は非常に重要であると考えられる．

\section{引用文献}

1) 持永早希子, 松永尚, 江本晶子, 平野和裕, 田崎正信, 齋田哲也, 土肥佐和子，佐藤清治，末岡榮三朗，末岡尚 子, 林真一郎, 藤戶博, がん化学療法における医療過誤
予防への Failure Mode and Effects A nalysis(FMEA)の応 用，医療薬学，10，1050-1058 (2006).

2) 桜田宏明, 森田和彦, 青山佳晃, 北村邦朗, がん化学療 法レジメン認定分会の取り組みと薬剂師の役割，日本病 院薬剂師会杂隹誌，43，677-680 (2007).

3) 高橋鄉, 川上和宜, 青山岡, 平岡知子, 白井健之, 今田 洋司，杉山肇，樋口秀太郎，杉㠃崇人，安藤花留，芳賀 洋子，柴田佳子，近藤智恵子，中村安生，濱敏弘，電子 カルテシステムを用いたがん化学療法の処方監査の確 立, 日本医薬品情報学，9，17-24 (2007).

4) 宮田広樹, 片山志郎, 西澤光代, 本城和義, 輪湖哲也, 伊勢雄也，腹子あきこ，若林恵子，古賀美帆，藤田倫子， 大嶺桂子，菊池有道，弦間昭彦，外来がん化学療法にお ける薬剂適正使用推進と薬剂費節減効果, 日本病院薬剂 師会杂隹誌，43，657-659 (2007).

5) 川島理恵子, 相良英憲, 河崎陽一, 横山紀子, 松香直 行，松永尚，千堂年昭，五味田裕，外来がん化学療法に おける疑義照会内容の医療経済学的検討，医療薬学， 10, 883-887 (2007).

6) 岩本卓也 , 佐々木典子 , 杉本浩子 , 石橋美紀 , 川瀬亮 介，奥田真弘，入院がん化学療法の安全実施に向けた無 菌調製担当薬剂師と病棟担当薬剂師との処方鑑査の連 携，日本病院薬斉師会杂倠誌，43，1065-1069 (2008).

7) 今田洋司, 川上和宜, 平岡知子, 樋口秀太郎, 高橋鄉, 青山岡，篠崎英司，末永光邦，松阪諭，濱敏弘，FOLFOX 4 療法の副作用集計データに基づく患者向け説明書 の作成, 癌と化学療法 , 34, 1425-1430 (2007). 